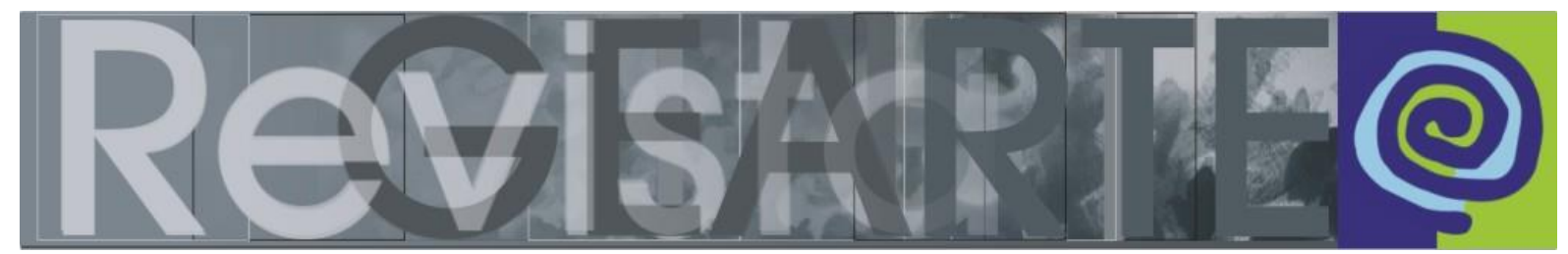

ISSN 2357-9854 | e-ISSN 2596-3198 (online)

\title{
Arte Pública: reflexões e possibilidades
}

\author{
Sandra Conceição Nunes \\ (Universidade do Estado de Santa Catarina - UDESC, Florianópolis/SC, Brasil; \\ Prefeitura Municipal de Florianópolis - PMF, Florianópolis/SC, Brasil) \\ Sandra Regina Ramalho e Oliveira \\ (Universidade do Estado de Santa Catarina — UDESC, Florianópolis/SC, Brasil)
}

\begin{abstract}
RESUMO - Arte Pública: reflexões e possibilidades - A Arte Pública, obras instaladas em espaços públicos ou privados, mas visíveis aos transeuntes, está presente nos mais diferentes locais do Brasil e do mundo. Em Florianópolis se tem um acervo de mais de trezentas obras distribuídas em diferentes bairros, produzidas em períodos distintos por dezenas de artistas. Acreditando na importância de valorização e utilização deste acervo nas aulas de Artes, esse texto busca refletir sobre algumas questões que envolvem o tema, o qual está sendo objeto empírico de uma tese de doutorado intitulada "Arte Pública e Ação Educativa: interações de estudantes com o acervo do Município de Florianópolis".
\end{abstract}

PALAVRAS-CHAVE

Arte Pública. Espaço Urbano. Cidade de Florianópolis. Ensino de Arte.

ABSTRACT - Public Art: reflections and possibilities - Public Art, works installed in public or private spaces, but visible to passers-by, is present in the most different places in Brazil and in the world. Florianópolis has a collection of more than three hundred works distributed in different neighborhoods, produced at different periods by dozens of artists. Believing in the importance of valuing and using this collection in Arts classes, this text seeks to reflect on some issues that involve the theme, which is being the empirical object of a doctoral thesis entitled "Public Art and Educational Action: student interactions with the collection of the Municipality of Florianópolis".

KEYWORDS

Public Art. Urban Space. Florianópolis city. Art education.

RESUMEN - Arte público: reflexiones y posibilidades - Arte Público, obras ubicadas en espacios públicos o privados, pero visibles a los peatones, se encuentran en los más diversos sitios de Brasil y del mundo. Florianópolis tiene una colección de más de trescientas obras ubicadas en los diferentes barrios de la ciudad, hechas por artistas locales en períodos diversos. Creyendo en la importancia de valorar y usar esta colección en las clases de Arte, este texto busca reflexionar sobre algunas cuestiones que involucran la temática, que está siendo objeto empírico de una tesis doctoral titulada "Arte público y acción educativa: interacciones de los estudiantes con la colección del Municipio de Florianópolis".

\section{PALABRAS CLAVE}

Arte Público. Espacio Urbano. Ciudad de Florianópolis. Educación Artística. 


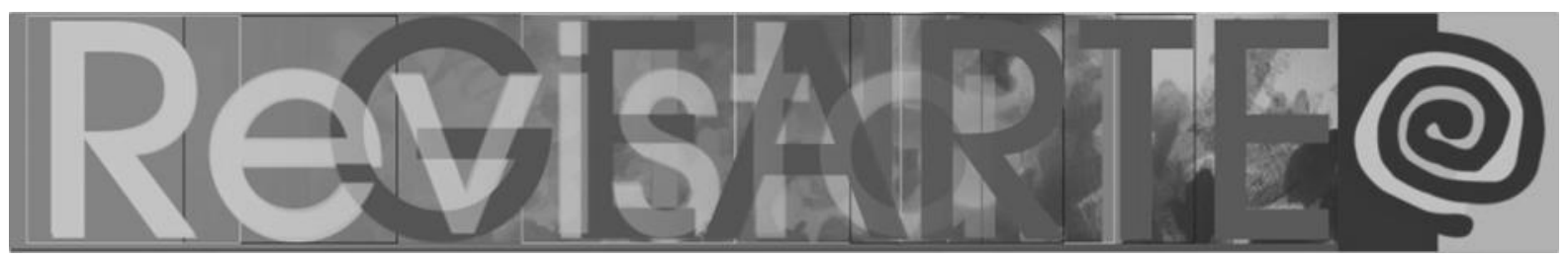

\section{Para as políticas públicas chegarem ao público}

Este texto busca dar destaque a políticas públicas de constituição de acervos de arte que nem sempre são entendidos enquanto tal, nem pela população das cidades onde se situam, e nem mesmo pelos professores de Arte. Se essa categoria de arte recebe a adjetivação de pública é porque é de todos e, portanto, deveria ser acessível a todos, à maioria da população. No entanto, obras dispersas no caos urbano passam despercebidas e a escola, nas aulas de Arte, poderia evidenciar e problematizar tal patrimônio cultural junto aos estudantes, para que eles pudessem se apropriar do que, em última análise, é seu.

Na nossa experiência na pesquisa de campo que, também, é parte integrante da tese da qual este artigo é um recorte, percebeu-se que, além de os professores de Arte não se darem conta de que há um acervo disponível para a vivência presencial da interação com essa categoria artística, os estudantes, muitos tendo alguma dessas obras instaladas no próprio edifício onde moram, acabam entendendo que seja algo apenas decorativo, sem um valor maior. E sabe-se, de acordo com os estudos semióticos mais recentes (LANDOWSKI, 2004, 2014, 2017), que as relações de interação em relação direta com pessoas ou coisas são as mais potentes para a geração de sentidos e significados. Como geralmente nós, professores, temos que nos servir de reproduções para nossas aulas, oportunidades para o contato presencial com a obra de arte parecem mais que oportunas.

O corpus de análise específico, o qual será nossa referência, é o acervo de Arte Pública do Município de Florianópolis. Sendo uma de nós professora de Arte deste município e tendo atuado ambas, orientanda e orientadora, na Comissão Municipal de Arte Pública de Florianópolis/COMAP, o diálogo proposto entre essas duas pontas da comunicação cultural, ou seja, entre as políticas públicas para a arte e os alunos das escolas, parece não apenas evidente, como necessário.

Assim, fica definido nosso objeto de estudo como o acesso a esses bens culturais; daí surge a necessidade da oferta de meios para a apreensão do público 


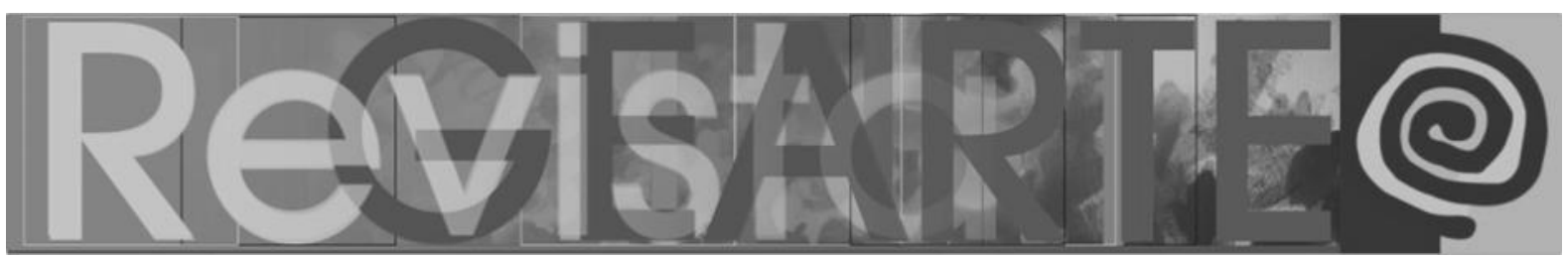

da arte do que o rodeia na sua cidade, pois essa categoria artística está exposta permanentemente aos transeuntes e raramente é percebida; por outro lado, há a possibilidade de a escola se apropriar desta categoria como conteúdo das aulas de Arte, o que já está ocorrendo nas duas instituições educacionais onde foi desenvolvida a pesquisa de campo: a Arte Pública passou a fazer parte dos currículos. Isto foi absorvido pelo entendimento dessas instituições da importância da arte na escola, pois além de serem os futuros cidadãos, os alunos, ao se darem conta da existência da Arte Pública e discutirem seu potencial, levando para a construção de "ser cidadão", ou seja, a constituição do indivíduo que tem direitos a usufruir e deveres a cumprir, os trabalhos e as pesquisas propostos para casa, bem como seus comentários em família, têm contaminado os pais para o entendimento da função questionadora desses objetos de arte, entendidos como apenas artefatos, levando-os a refletir e não apenas a considera-los como um item a mais na fachada em um prédio ou em praça pública, como uma espécie de totem decorativo ou como a cereja do bolo.

Para este artigo, além da adaptação do recorte da tese, adotamos como metodologia a pesquisa histórica sobre a temática, incluindo a memória e a pesquisa de campo, percorrendo e fotografando alguns exemplares da Arte Pública da cidade, bem como a pesquisa nas legislações que regulam a implantação da Arte Pública em Florianópolis, como decretos e o Plano Diretor do Município. Trata-se de um resgate histórico de uma manifestação urbanística, do desenvolvimento de políticas públicas municipais, da discussão sobre a impossibilidade de limites ao conceito de arte pública e de sugestões de possibilidades para o uso de um acervo que, uma vez conhecido, possa ser usufruído por quem de direito, os diversos públicos, e entendido em suas respectivas camadas, incluindo os estudantes dos diversos níveis.

Embora nosso foco seja o acervo de Arte Pública de uma cidade específica, Florianópolis, acreditamos que o tema e as reflexões aqui expostos possam servir para outros contextos, uma vez que esse tipo de produção está presente em 


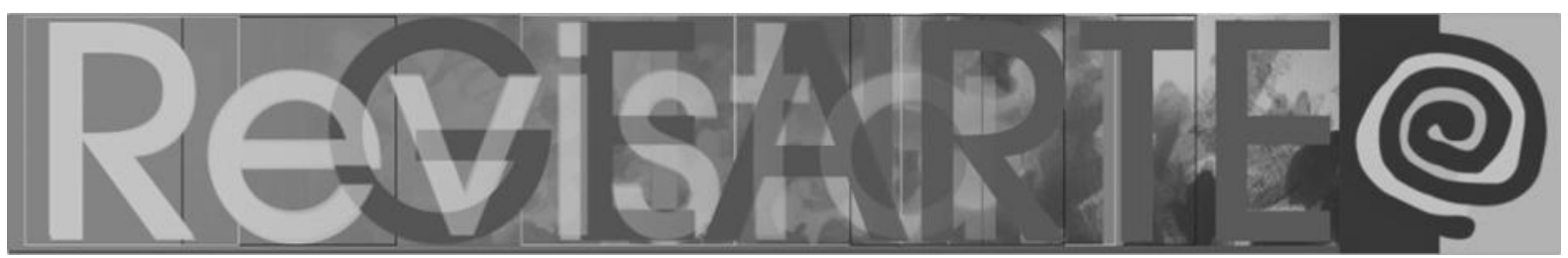

diferentes cidades do país e do mundo, como poderá ser observado adiante, por meio de alguns exemplos.

\title{
Obras públicas precursoras
}

As primeiras imagens estéticas ${ }^{1}$, pois não podemos considerá-las, em sua essência, imagens artísticas, uma vez que diversas delas são exclusivamente decorativas, ou enaltecedoras do poderio de figuras de governantes - oferecidas à apreciação do público —, apareceram inicialmente, em Florianópolis, em praças ou edifícios públicos.

Entre as imagens precursoras da Arte Pública, considerando o conjunto de elementos estéticos visuais acessíveis a quem transita na cidade, tivemos e ainda temos hoje "ornamentos da arquitetura local, em edificações que datam de finais do século XIX e da primeira metade do século XX, os quais compõem o chamado estilo eclético daquele período histórico". (RAMALHO E OLIVEIRA, 2010, p. 91).

Ainda segundo a autora, este estilo, eclético por definição, une distintos elementos da arquitetura do barroco e do neoclássico, dentre outros, tendo como melhores representantes na cidade o Palácio Cruz e Sousa, o casarão da família Carvalho, no bairro Agronômica antigo Santa Catarina Country Club, e o que hoje tornou-se um salão de festas no Residencial Country Club, localizado na Avenida Beiramar. Ramalho e Oliveira (2010, p. 91) acrescenta:

\begin{abstract}
Ainda podem ser entendidas como precursoras da Arte Pública as imagens estéticas, - e não artísticas, pois têm finalidades utilitárias, quais sejam, políticas - mas que podem ser consideradas como públicas por estarem expostas ao olhar do público, os monumentos erigidos nas praças públicas. Tratam-se, geralmente, de bustos e estátuas de governantes, cidadãos relevantes para a história local ou nacional ou mesmo os considerados heróis, como Marechal Deodoro, Annita Garibaldi, Carl Hoepcke, Esteves Júnior, Nereu Ramos, Celso Ramos.
\end{abstract}




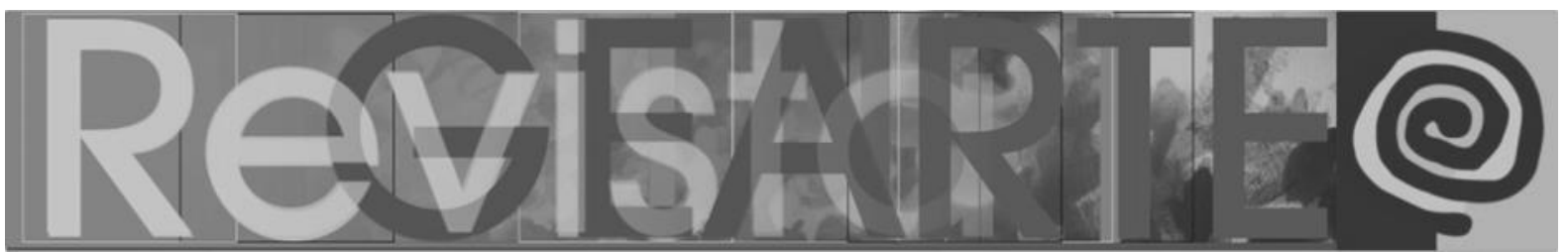

Figura 1 - Monumento em homenagem à Annita Garibaldi, alocada na Praça Getúlio Vargas, no Centro de Florianópolis

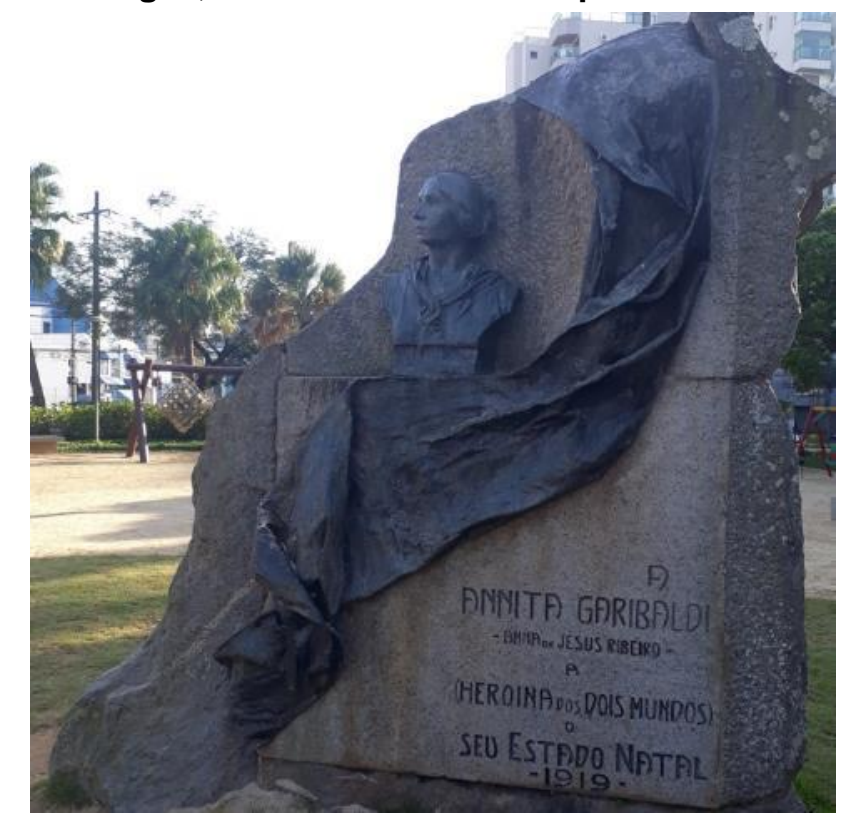

Fonte: Acervo das autoras.

Annita Garibaldi, ou Ana Maria de Jesus Ribeiro, foi uma catarinense da cidade de Laguna que se tornou esposa do italiano Giuseppe Garibaldi, acompanhando-o em muitas de suas lutas, na América Latina e na Itália, daí ser considerada a "heroína dos dois mundos", conforme a inscrição na placa da Figura 1. Se na Itália em quase todas as cidades há uma rua ou praça Garibaldi, referindose a Giuseppe, pois ele foi o grande responsável pela unificação da Itália para que se tornasse um só país, Annita também tem logradouros públicos com seu nome longe de seu país natal, inclusive em pequenas cidades da Itália. Essa homenagem, mais histórica do que estética ou artística, foi uma motivação para a inserção de tais artefatos no espaço público na época, é até tímida diante da sua figura.

Nossas referências a estilos e às influências de estilos se devem ao fato de que, como os demais professores de Arte, potenciais leitores deste artigo, temos anos de estudos de História da Arte, o que nos poupa de buscar e nos justificar por meio de citação de fontes mais reconhecidas, cujos conhecimentos já temos introjetados. 


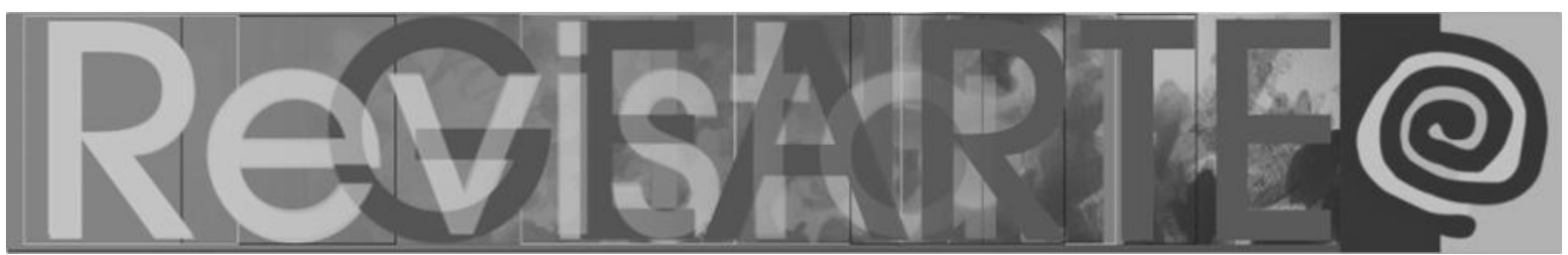

Um outro estilo é evidenciado na metade do século XX, também eclético, com influências "do art déco, da Bauhaus, de Niemeyer e, finalmente, das adaptações procedidas pela inventividade local; era então chamado de estilo 'funcional' ou 'moderno'". (RAMALHO E OLIVEIRA, 2010, p. 91). Segundo a autora, destaca-se uma predominância de linhas retas, principalmente nos telhados com ângulos obtusos, como também o uso de elementos vazados nas fachadas - módulos de vidro ou cerâmica cozida e esmaltada.

\begin{abstract}
É desta época o uso dessas pequenas pastilhas coloridas como revestimento, o que propiciava a presença dos mosaicos como ornamento de fachadas. Entre eles, em Florianópolis, podemos destacar algumas obras. Um mosaico, mural situado no andar térreo do antigo edifício do IAPC (Instituto de Aposentadoria e Pensões dos Comerciários), [...] defronte ao Teatro Álvaro de Carvalho, ainda preservado; o mural, também mosaico em pastilhas, de autoria de Martinho de Haro, [...] na esquina da Rua Sete de Setembro com a Rua Felipe Schmidt, no centro da cidade, igualmente ainda preservado. (RAMALHO E OLIVEIRA, 2010, p. 92-93).
\end{abstract}

Além destes, tem-se um mosaico de Rodrigo de Haro, no andar térreo do Centro Comercial Aderbal Ramos da Silva, mais conhecido como ARS, diante do qual se situa um chafariz (Figura 2). As três obras, como pode ser observado, possuem características modernistas.

Figura 2 - Na sequência, da esquerda para a direita, mosaicos presentes nas edificações: Núcleo Estadual do Ministério da Saúde; Instituto do Meio Ambiente; e Centro Comercial Aderbal Ramos da Silva
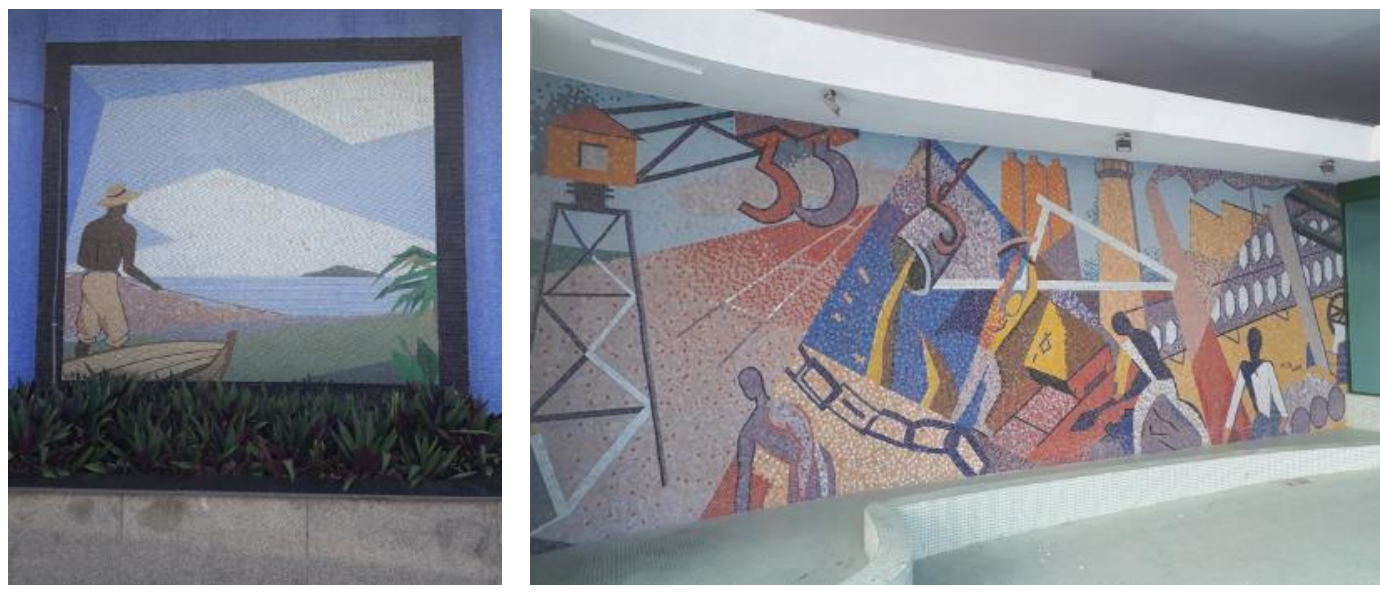

NUNES, Sandra Conceição; OLIVEIRA, Sandra Regina Ramalho e. Arte Pública: reflexões e possibilidades.

Revista GEARTE, Porto Alegre, v. 8, n. 1, p. 46-65, jan./abr. 2021.

Disponível em: http://seer.ufrgs.br/gearte 

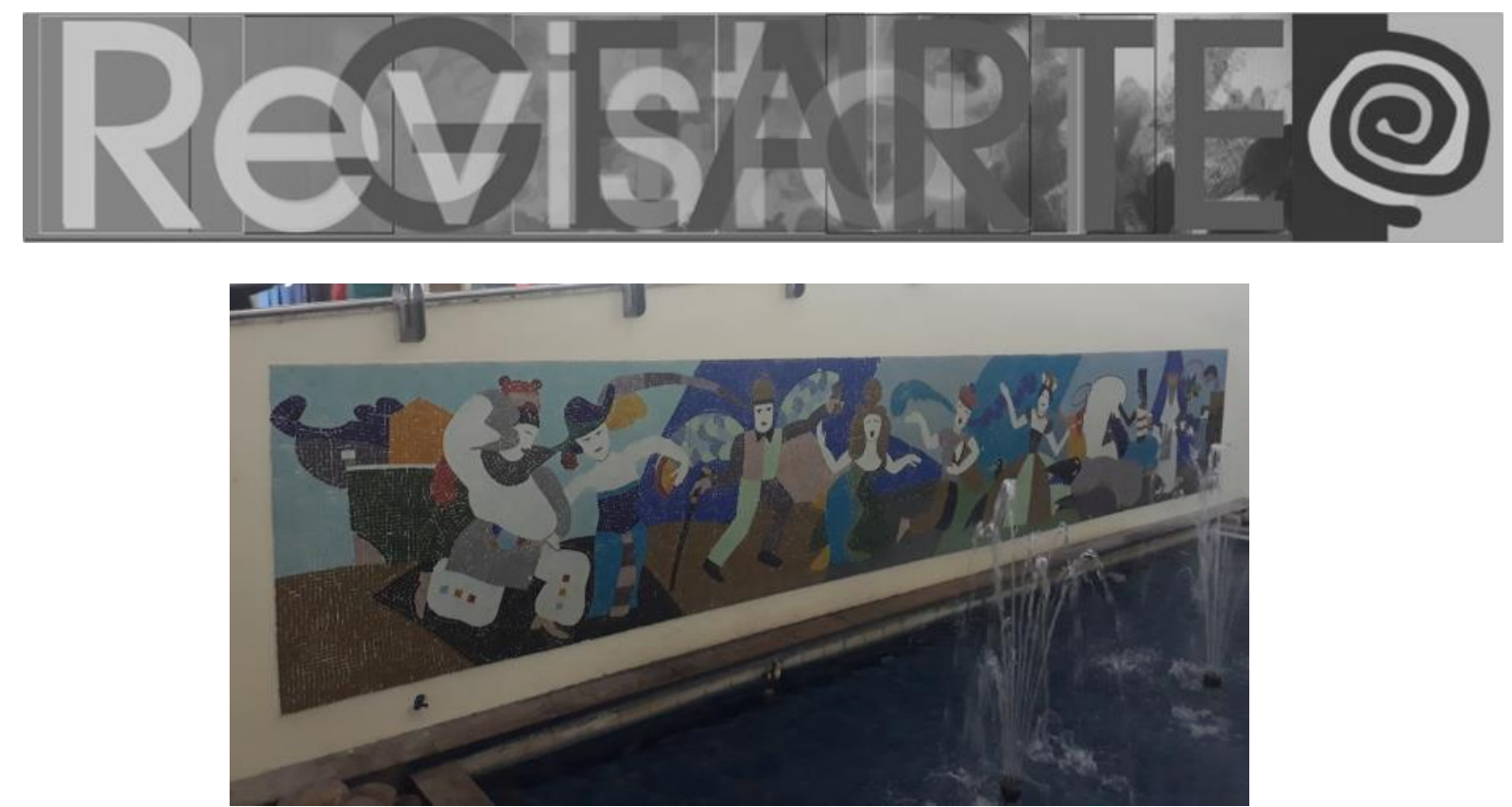

Fonte: Acervo das autoras.

É preciso considerar também outros dois murais presentes em residências, ambos localizados em uma das principais e mais conhecidas ruas da cidade, a Avenida Rio Branco. Sobre eles, Ramalho e Oliveira (2010, p. 93) destaca:

\begin{abstract}
Um deles, na outrora residência do Deputado Dib Cherem, tendo como temática a ponte Hercílio Luz e o pescador, painel hoje destruído ou obliterado, no prédio que abriga um dos restaurantes da cadeia Porto. O outro, também um mural em pastilhas, colorido, exemplar do abstracionismo geométrico, orgânico, situava-se na já destruída residência do ex-prefeito Osmar Cunha, em outra quadra da mesma Avenida Rio Branco.
\end{abstract}

Uma curiosidade acerca destas duas obras é que ambas se situavam nas fachadas de duas residências de dois ex-prefeitos de Florianópolis; ambas, painéis em mosaico colorido, ambas perdidas irremediavelmente. Dada a exclusividade do mural abstrato, único desta modalidade de arte nesta concepção, uma busca junto à família reiterou a pouca importância a ele dispensada, pois sequer uma foto restou.

A cidade recebe tempos depois outro mural, desta vez de Willy Zumblick, em um edifício residencial denominado Edifício Presidente, que pode ser visto até hoje na esquina da Rua Presidente Coutinho com a Avenida Gama D'Eça. Embora pouco visível pelo desgaste da tinta, recentemente a fachada em que ele está foi cercada por uma cortina de vidro transparente, delimitando uma área reservada aos moradores, mas ainda permanecendo visível aos transeuntes. 


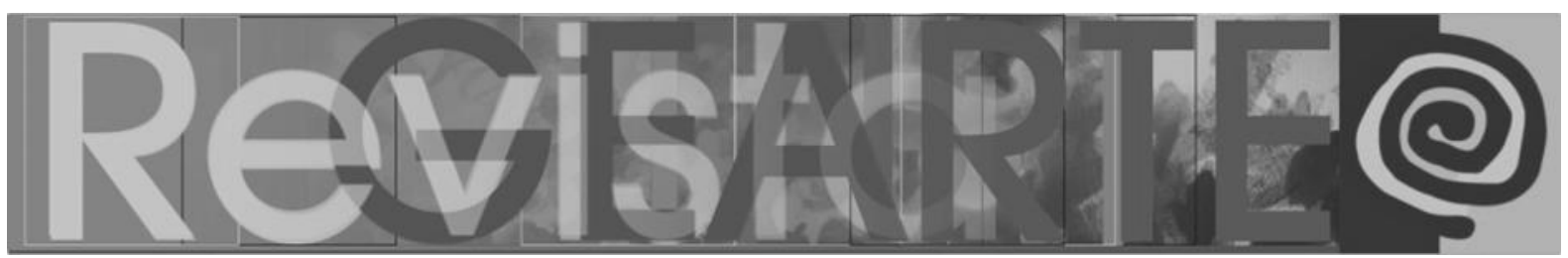

As obras implantadas no espaço público representam marcos de diversos períodos históricos, identificáveis, também, pelas características de estilo de diferentes épocas. Em Florianópolis, como em qualquer outra cidade do país ou do exterior, as obras submetidas ao olhar do público contam e testemunham as diversas camadas da sua história; e a própria história da Arte Pública merece ser conhecida pelos estudantes e pela população.

\title{
A institucionalização da Arte Pública em Florianópolis
}

Somente no final da década de 1980 é que surge o conceito de "Arte Pública". A partir de 1990, a municipalidade de Florianópolis, mediante a Lei Municipal n 3255/1989², procurou "estimular a implantação de obras de arte nas edificações, em troca da possibilidade da ampliação do gabarito de área construída, geralmente, em prédios de apartamentos" (RAMALHO E OLIVEIRA, 2010, p. 94) ou salas comerciais. A capital catarinense foi uma das primeiras cidades do país a adotar normativas para inserir obras no espaço da cidade e, ao longo de décadas, constituiu uma Política Municipal de Arte Pública. Como resultado, hoje se tem um acervo de mais de 300 (trezentas) obras acessíveis à sua população e visitantes.

Isto se deve a uma articulação de membros da Associação Catarinense de Artistas Plásticos (ACAP), conduzida pelo falecido artista visual e crítico de arte João Otávio Neves Filho, conhecido por Janga, que levou à gestão municipal da época a demanda de criar normativas para inserção de obras no espaço da cidade. Acerca desta fase, Ramalho e Oliveira (2010, p. 94) nos diz,

\begin{abstract}
Inicialmente, poucos eram os artistas que tinham conhecimento da Lei, e muitos dos que a conheciam, não ousavam participar da novidade. $E$ mesmo as construtoras, elas nem sempre tinham conhecimento da possibilidade e, menos ainda, sabiam como selecionar artistas, de modo a contribuir para a qualificação do acervo de Arte Pública de Florianópolis.
\end{abstract}

Nos anos iniciais dessa legislação, pode-se concluir que os construtores não compreendiam o conceito de arte, uma vez que entendiam como sendo decoração. Também se percebia que eles eram procurados por aqueles que diziam ser 


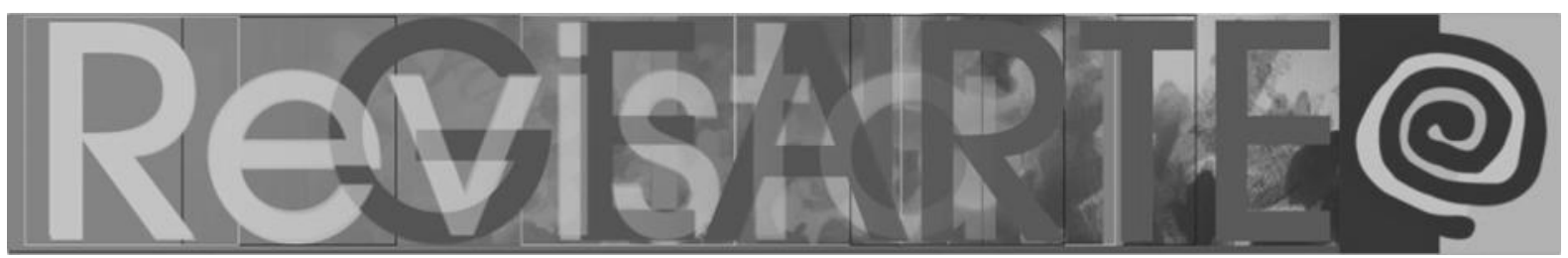

artistas, ou o inverso também ocorria. Como moeda de troca, o trabalho artístico possibilitava a ampliação da área construída.

A proposta, então, era analisada por uma comissão vinculada ao Instituto de Planejamento Urbano de Florianópolis (IPUF), órgão da administração pública da capital catarinense. As propostas aprovadas não necessariamente, hoje, seriam consideradas como arte, de acordo com os critérios atualmente adotados pela COMAP, a Comissão Municipal de Arte Pública, que rechaça os 3 "Ds": decorativo, dejà vu e descompromissado (sem qualquer questionamento social, político, ambiental).

Um conceito mais consistente de Arte Pública na cidade apareceu mais tarde, resultado de uma nova composição da Comissão Municipal de Arte Pública (COMAP), fato ocorrido em 2000. Ramalho e Oliveira (2010, p. 95) considera como preponderantes para isso:

[...] a coordenação de uma artista plástica visual integrante do quadro de funcionários do IPUF, Lú Pires e, em especial, a contribuição dos conhecimentos do professor dos cursos de graduação e pós-graduação de Arquitetura da Universidade Federal de Santa Catarina (UFSC), César Floriano.

As experiências vividas por esse professor no Brasil e seu doutoramento sobre a temática realizado na Espanha, foram muito importantes nesse processo. Sabe-se que a Espanha é referência no assunto e desenvolve políticas para levar obras de arte para o espaço público, além de ter exemplares de arquitetura inovadora, que o qualificam, igualmente, como é o caso de Barcelona (Figura 3). 


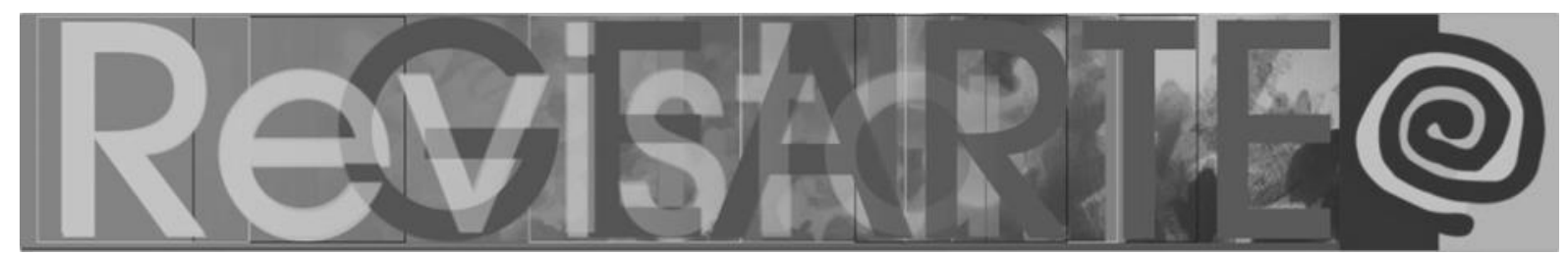

Figura 3 - Um bebedouro art déco nas ruas de Barcelona: mesmo um equipamento público utilitário pode ser transformado em arte

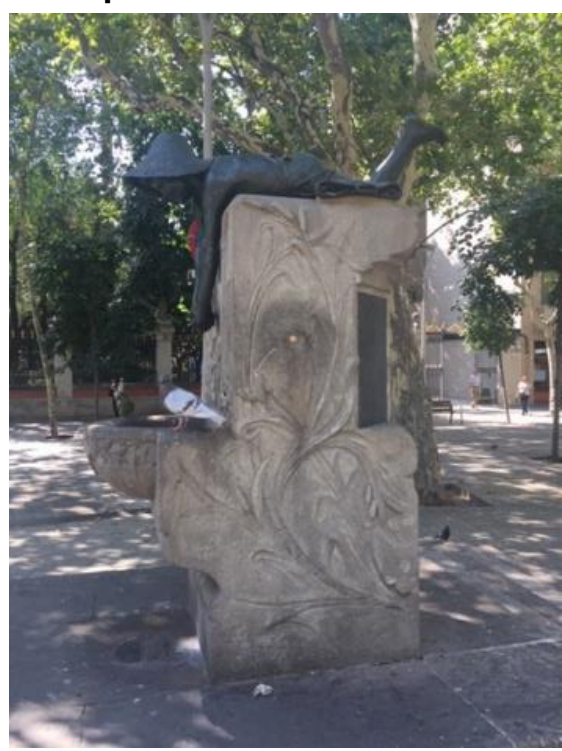

Fonte: Acervo das autoras.

A atuação da Comissão tem uma política de qualificação da Arte Pública de Florianópolis: ao invés de apenas aprovar ou reprovar propostas, emite pareceres consubstanciados, nos quais aponta as incoerências, inconsistências ou inadequações, estéticas, conceituais ou ergonômicas, acerca das obras não aceitas, com teor pedagógico para orientar os artistas. Também foram importantes os diálogos com os artistas e com os construtores, oportunizados principalmente durante as cinco edições do Seminário Municipal de Arte Pública, a partir de 2003.

\begin{abstract}
A Comissão também não se furta a dialogar com os artistas ou empresários que se dispõem a tal, formal ou informalmente, explicitando seus critérios e mesmo até apontando possibilidades de alterações nas obras, o que suscitaria outra vertente de discussões. Trata-se de questão de ordem ética. Entretanto, todos os esforços são direcionados no sentido do bem comum, por meio da proposição de uma maturidade estética e conceitual para o espaço público municipal. (RAMALHO E OLIVEIRA, 2010, p. 96).
\end{abstract}

Como resultado desse processo, Florianópolis recebeu obras permanentes em consonância com a produção artística atual, produzidas principalmente por artistas residentes na cidade. Algumas delas permitem que o público as manipule e outras apresentam a função de mobiliário urbano. O fato é que cada vez mais os trabalhos foram colocados mais próximas do público e sem barreiras visuais entre eles ${ }^{3}$ — público e obra. É a luta da COMAP se realizando, ao aproximar a arte, que é pública, do público. 


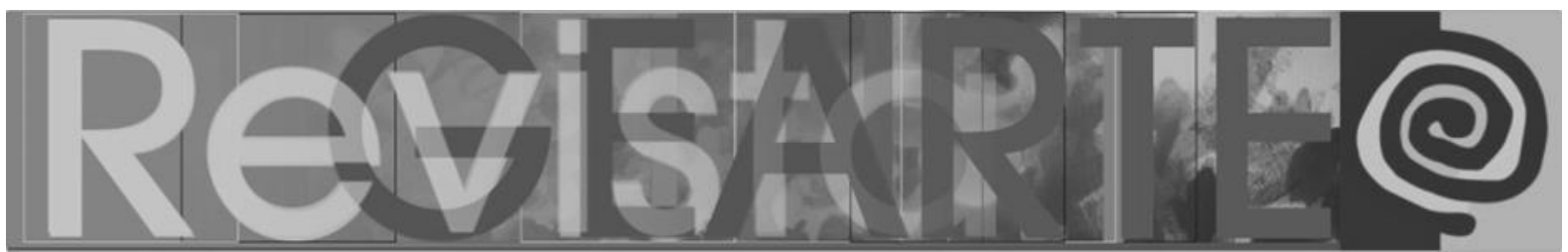

Mais recentemente, após a reformulação na legislação ocorrida em 2014, foram implantadas na cidade exemplares de produções de caráter permanente não apenas através de projetos submetidos pelos construtores, como também seleções públicas, por meio de editais. Por outro lado, as obras deixaram de ser instaladas somente nos limites do condomínio, ou seja, elas foram para o espaço público, como ruas e praças. Destacamos a inserção, em 2017, de cinco exemplares de mobiliário urbano (bancos) da Rua Tenente Silveira (Figura 4), uma das mais movimentadas da cidade; e a intervenção realizada em 2018 na Escadaria Pedro Soares, que recebeu sete esculturas de aproximadamente oitenta centímetros (Figura 5). Ambas as propostas foram selecionadas após lançamento de editais específicos, alocadas em espaços públicos, tendo como contrapartida do recebimento de acréscimos de índices de áreas edificáveis pelas construtoras.

Figura 4 - Intervenção com peças de mobiliário urbano na Rua Tenente Silveira, 2017. Na sequência, da esquerda para a direita: Nani Eskelsen, No azul; Rafael Rodrigues, Brinquedos da minha infância; e Edmilson Vasconcelos, Lembranças.
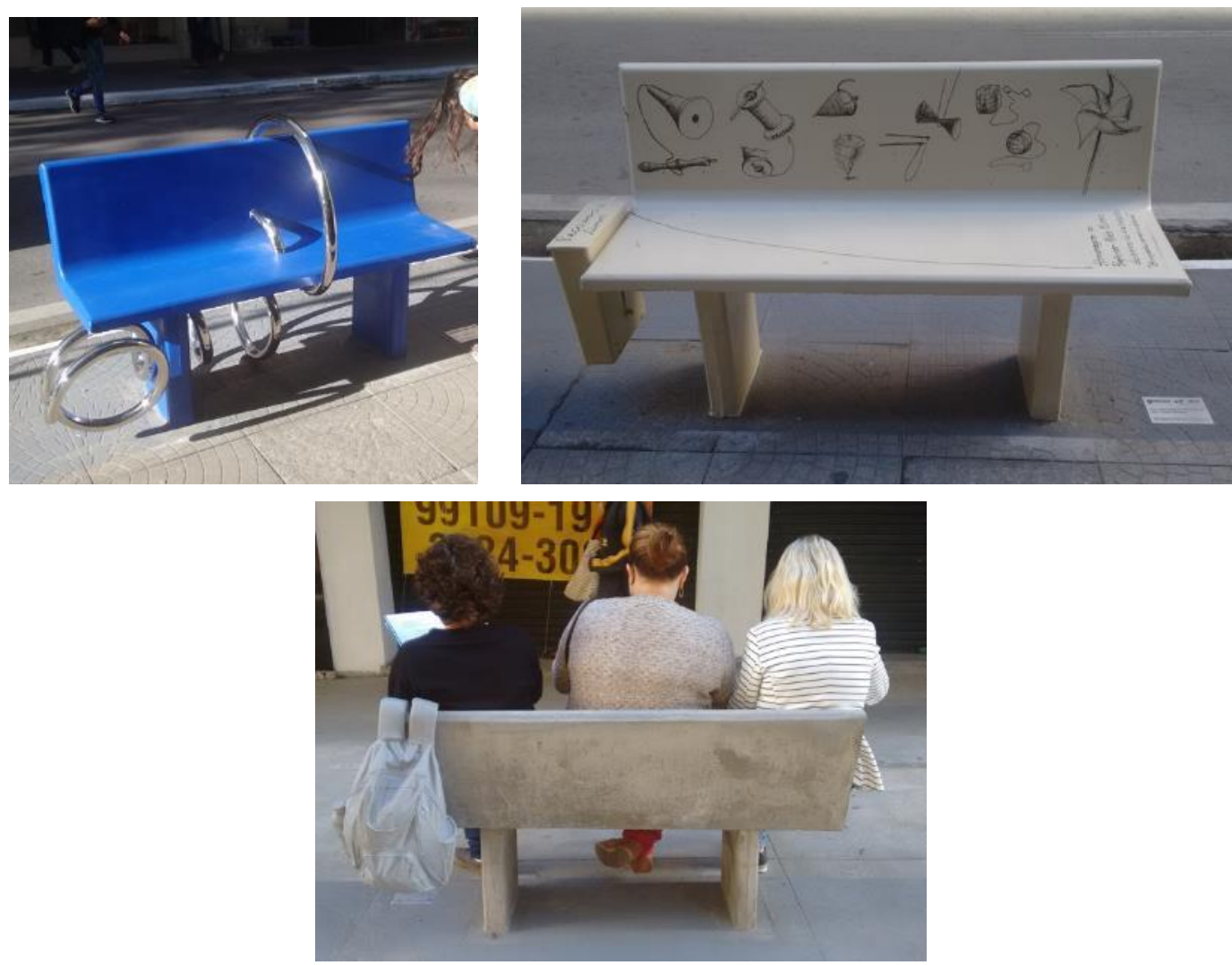

Fonte: Acervo das autoras.

NUNES, Sandra Conceição; OLIVEIRA, Sandra Regina Ramalho e. Arte Pública: reflexões e possibilidades. 


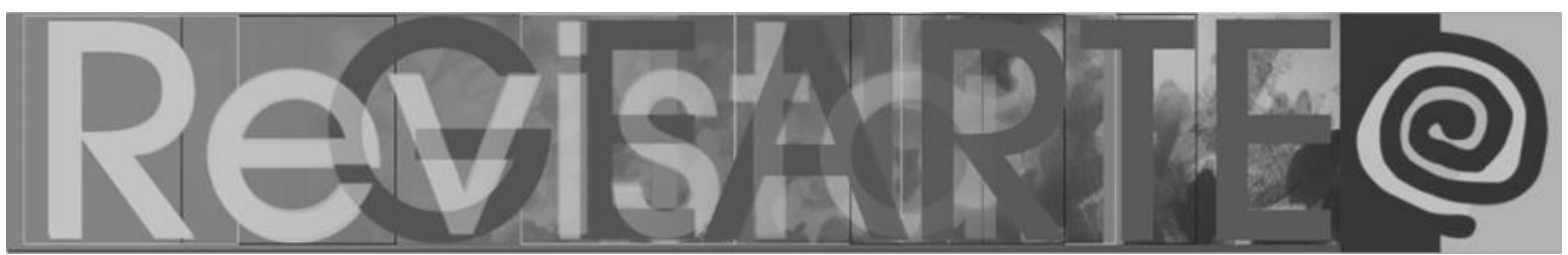

Figura 5 - Intervenção na Escadaria Pedro Soares. Edmilson Vasconcelos, Os Ubros, 2019

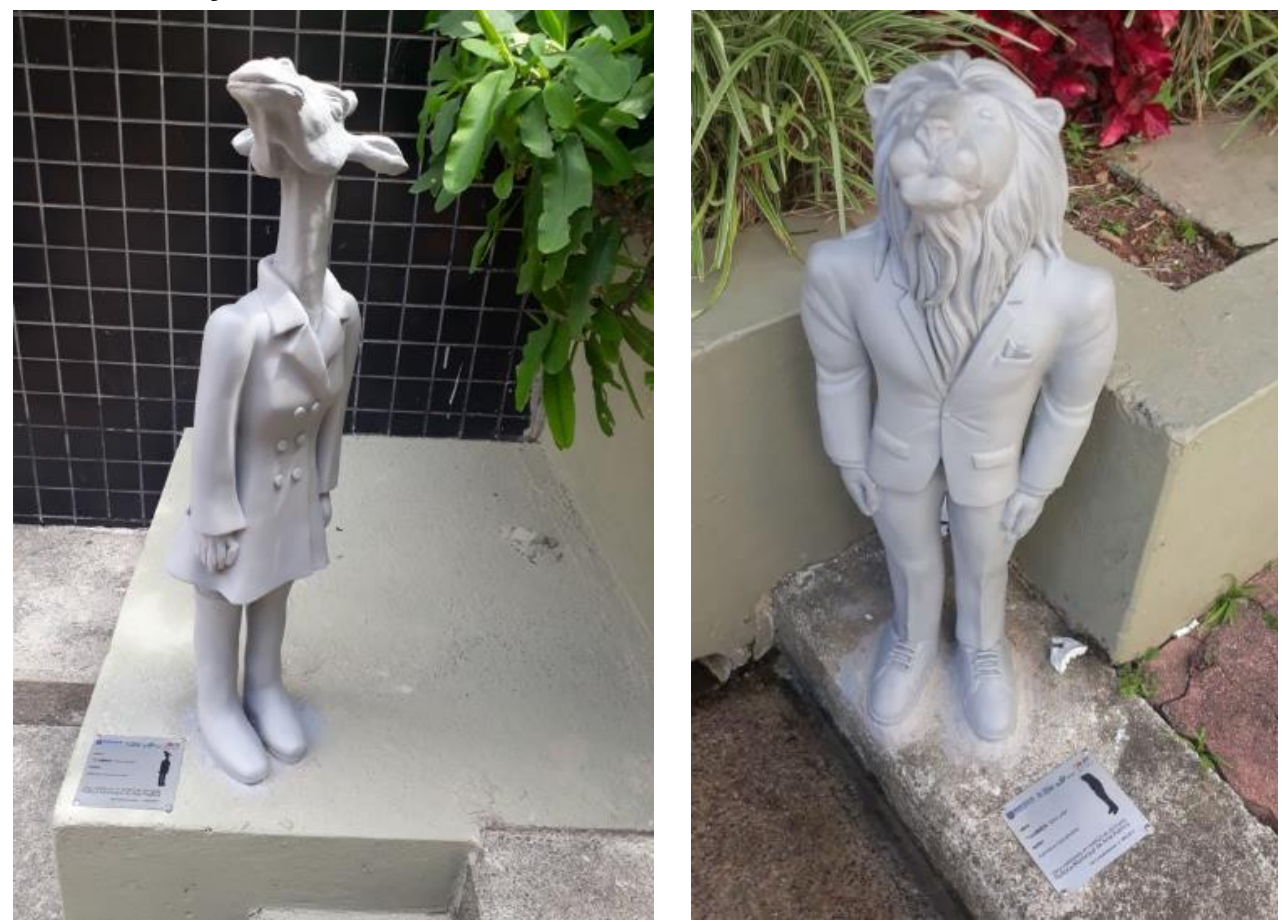

Fonte: Acervo das autoras.

\section{Arte Pública: uma prática em um campo expandido}

Questiona-se, então, quais os limites da Arte Pública, se é que eles existem. É fundamental levar em conta que, no espaço público, o privado deixa de assim sê-lo e, também, se torna público. O que veem os transeuntes que passam pelos logradouros urbanos ultrapassa as fronteiras das propriedades particulares; ao mesmo tempo, mesclam-se a arquitetura, a arte e outras mídias, como a publicidade, além das fiações e postes, pontos de ônibus, terrenos baldios e muros pichados, tudo se impõe ao público, numa total promiscuidade visual e social, gerando outras questões, de ordem ética.

A impossibilidade de se limitar os espaços público e privado, quando se trata de arte, que é algo para ser analisado. Fávero (2003, p. 66) afirma que "não só os espaços públicos são públicos". E segue a autora assim justificando sua proposição:

Isso quer dizer, sim, que existem espaços institucionais inseridos em organizações públicas destinadas a outros fins ou mesmo destinadas 


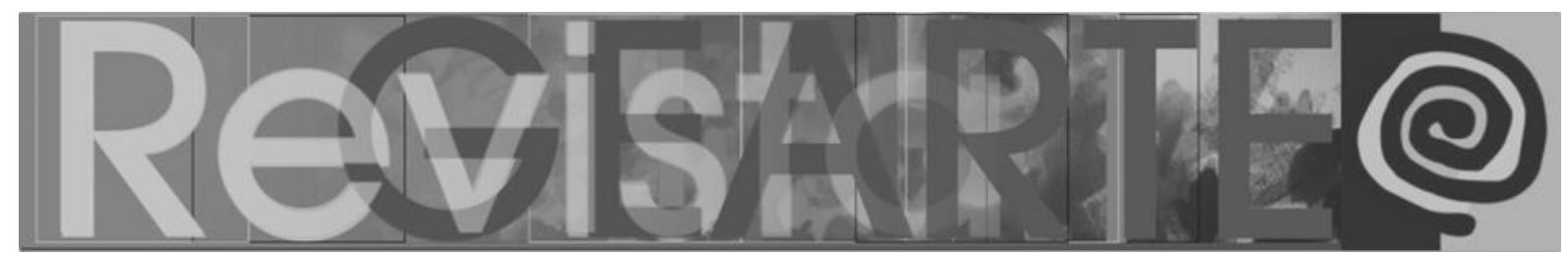

especificamente a divulgar e promover a arte. Mas existem outros espaços na cidade usados para exposições de arte que são privados porque não se trata de entidades governamentais; são propriedades particulares, pois têm proprietários específicos, no entanto, como são abertos ao público, como cobram (ou não) ingressos e como esse público pode até ser mais numeroso, já que se dirige ao local com outros objetivos, há um uso público também nesses espaços. Assim, o uso público de espaços privados faz com que não só os espaços de exposição públicos sejam públicos.

Excetuando-se as obras e construções intra muros e fechadas ao público, tornam-se públicos, independentemente da vontade de quem quer que seja, princípios e valores, ao se exporem formas, figuras ou simples elementos decorativos nas fachadas de casas e edifícios, pois qualquer forma de interação com os diversos públicos gera significados e sentidos.

De acordo com Argan (1984, p. 233),

[...] faz urbanística o escultor, faz urbanística o pintor, faz urbanística até mesmo aquele que compõe uma página tipográfica, faz urbanística qualquer um que realize algo que, colocando-se como valor, mesmo em escalas dimensionais mínimas, entre no sistema de valores [...].

A cidade passa a ser, assim, o conjunto de expressões de artistas, às quais se agregam também expressões urbanísticas decorrentes de conflitos sociais, tanto quanto as resultantes de projetos de afirmação dos ocupantes dos poderes, presentes nas edificações públicas ${ }^{4}$. Deste modo, camadas de significados e sentidos se sobrepõem no decorrer dos anos a partir das marcas deixadas na cidade, ora descaracterizando traços de momentos históricos anteriores, ora associando novas marcas. O fato de não termos sofrido destruições de guerras, as demolições, reformas ou fachadas aplicadas para esconder as originais, talvez tenham surgido por uma espécie de sentimento de busca de atualidade, de preocupação em parecer antiquado ou fora de moda. Esta é uma característica cultural não apenas da nossa cidade, mas de muitas outras, em especial no nosso país, onde os centros históricos são separados do centro comercial, ou do centro político: vergonha do passado, desejo de apagar momentos anteriores, por ser entendido como atraso e, principalmente, como provincianismo. 


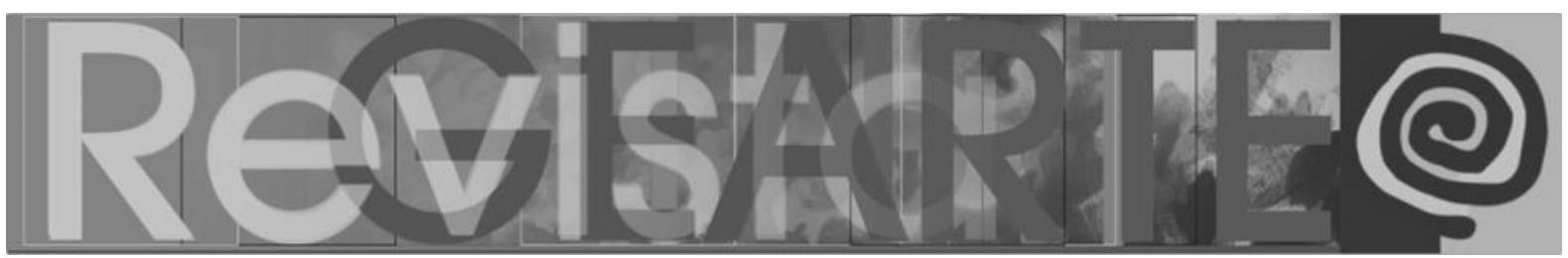

Querendo atualizar o aspecto urbano apagando ou maquiando a configuração de edificações há um exemplo notório em Florianópolis: a Catedral Metropolitana (Figura 6). Não se trata de uma construção barroca na origem, embora alguns ainda acreditem, mas sim um templo jesuítico de influência italiana. Seus altares e retábulos, que contém elementos barrocos, foram todos refeitos no século XIX e não se sabe como eram os originais. A então Igreja Matriz sofreu muitas intervenções ao longo dos anos, e foi somente a partir da década de 2000 que a edificação foi objeto, pela primeira vez, de uma restauração com acompanhamento técnico multidisciplinar. Anteriormente, as outras reformas iam, sucessivamente, descaracterizando a edificação original e atendendo às tendências arquitetônicas religiosas vigentes à época de cada reforma. Tanto é que, no restauro de 2000 , muitas camadas de tinta tiveram que ser literalmente raspadas, para se chegar mais próximo do mais antigo.

Figura 6 - Eduardo Dias, fachada original da hoje Catedral Metropolitana de Florianópolis

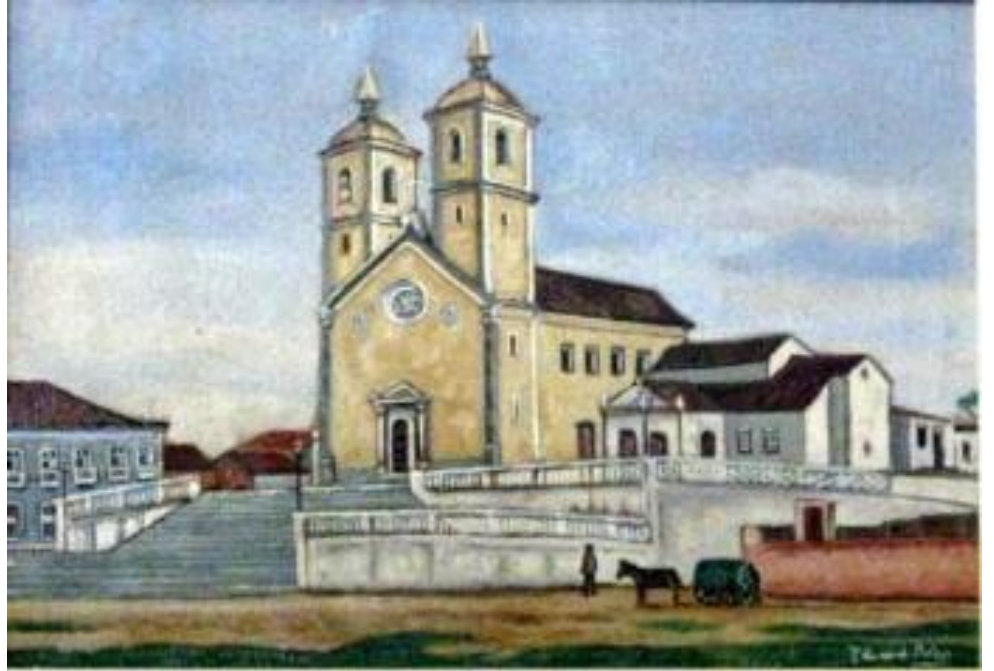

Fonte: Coleção particular de Sara Regina Poyares dos Reis. Foto: José Augusto Oliveira.

Outra maneira de subtrair as marcas da história no espaço urbano é intervindo danosamente, substituindo edificações e outros marcos urbanos, por meio de demolições ou obliterações. É o caso dos mosaicos das casas de Dib Cherem e de Osmar Cunha, talvez das mais valiosas obras de arte catarinense dos anos sessenta. 


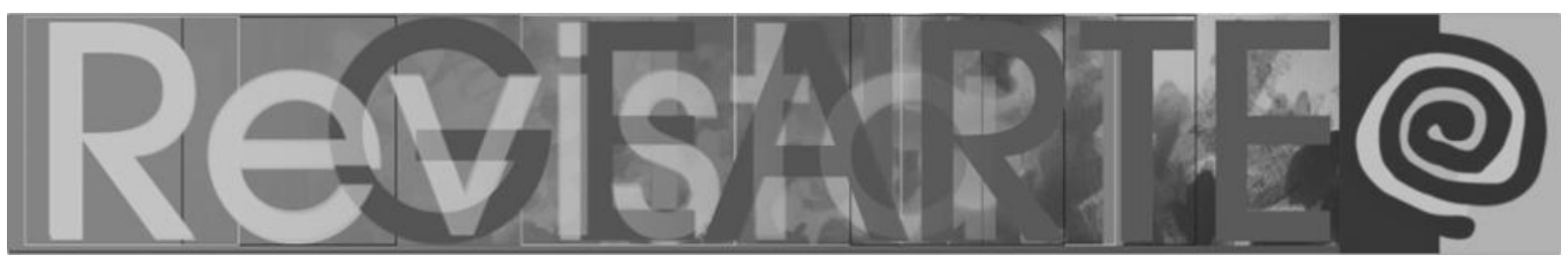

A preservação de fatias da história de cada período vivido por uma comunidade que se perpetua é fundamental para a compreensão da posteridade, sem se negar a importância do surgimento de edificações e elementos do contemporâneo justapostos aos anteriores sem, necessariamente, interferirem no que já estava posto. Não vamos nos esquecer que o contemporâneo de hoje é o histórico para a nossa posteridade.

Diz Calvino, a este respeito (2004, p. 14):

[...] a cidade se embebe como uma esponja dessa onda que reflui das recordações e se dilata. [...] Mas a cidade não conta o seu passado, ela o contém como as linhas da mão, escrito nos ângulos das ruas, nas grades das janelas, nos corrimões de escadas, nas antenas dos pararaios, nos mastros das bandeiras, cada segmento riscado por arranhões, serradelas, entalhes, esfoladuras.

Pesquisar, refletir e adotar nas aulas de Arte a questão da Arte Pública possibilita verificar os limites entre o moderno e o contemporâneo, ou os diálogos possíveis entre eles; buscar entender as diferenças e convergências entre o espaço público e o privado; pensar sobre as relações entre arquitetura e escultura; entre arte e decoração; entre arte e artesanato; entre a arquitetura e a jardinagem; entre o efêmero e o permanente; e ainda sobre a questão ambiental, para se perceber o sentido da preservação do patrimônio histórico, arquitetônico, mas também do patrimônio natural e do possível colapso do planeta. Cada um destes temas, mais do que meros enfoques, demandaria profundo exame e, provavelmente, profícuos resultados. Para exemplificar quantos enfoques se pode explorar com o tema Arte Pública, como as oposições citadas anteriormente, tomamos duas manifestações que, apesar de distantes da nossa realidade, mostram a potência dessa categoria de arte e sua ausência de limites: a seguir, à esquerda, uma expressão da Berlim contemporânea, ocidental: uma obra que busca a integração com a natureza, onde os elementos são a vegetação e a água; à direita, observamos resquícios da rígida estética da Berlim oriental (Figura 7). Como se percebe, há um grande contraste, que exprime questões ideológicas e temporais. 


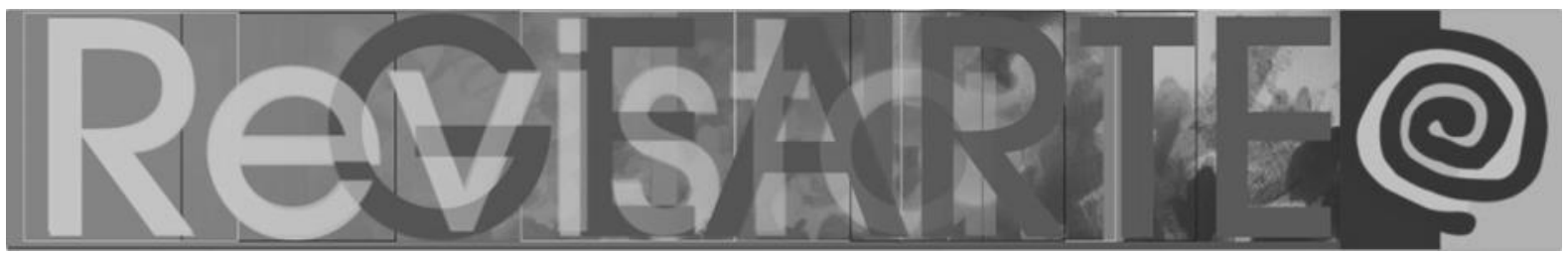

Figura 7 - Da esquerda para direita, Berlim, do lado da antiga Alemanha Ocidental: a estética urbana, desenhada com água e vegetação; e Berlim do lado da antiga Alemanha Oriental: imagens que ficaram da ocupação russa e de seu programa espacial
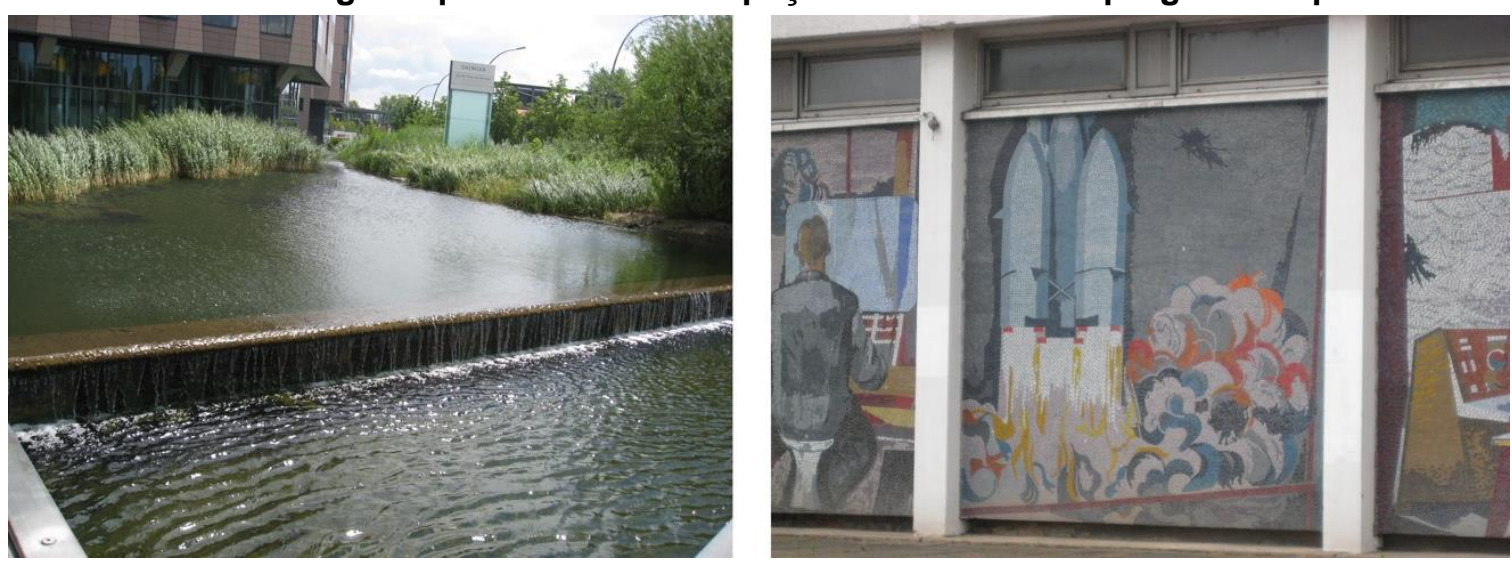

Fonte: Acervo das autoras.

Ou seja, Arte Pública pode ser um eixo, uma provocação ou uma motivação para se discutir sobre a própria questão da arte, em si, como também sobre a cultura, a história e aspectos sociais de uma cidade. Buscar estratégias para abordar esse tipo de produção de forma a construírem sentidos e significados faz parte dos desafios das professoras e dos professores. No ambiente citadino, os sujeitos se deparam com diferentes elementos culturais e artísticos, tornando-se importante a apropriação deles de forma crítica.

\section{Moratória da produção de artefatos}

Se, de um lado, é uma posição também ideológica tentar partilhar com um número maior de pessoas nossas reflexões, principalmente com os professores de Arte, é uma postura política propor agora a discussão sobre uma alternativa específica, motivada pelo foco voltado à Arte Pública. Trata-se da questão de adicionar mais objetos ao meio ambiente, ao se implantar objetos artísticos. $\mathrm{O}$ mundo está repleto de bens duráveis que se tornam inúteis, ou têm a sua durabilidade estendida após a sua utilidade.

E o que a Arte Pública tem a ver com isso? Todos e tudo têm a ver com isso. É o que tentam dizer, por exemplo, obras de Arte Pública de Dennis 


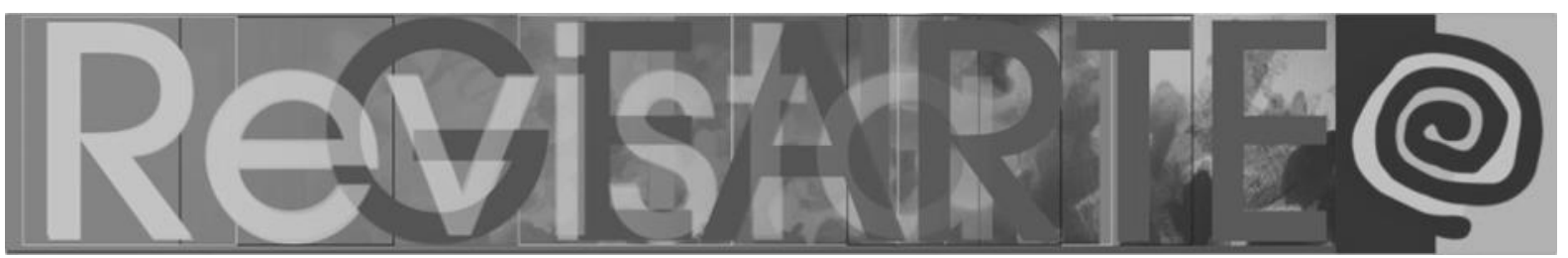

Oppenheim (2006), situadas em Potsdam, Alemanha, intituladas "Paisagens Alternativas para o Futuro" (Figura 8).

Figura 8 - "Paisagens Alternativas para o Futuro", de Dennis Oppenheim, no Shifftbauergasse, em Potsdam, 2006
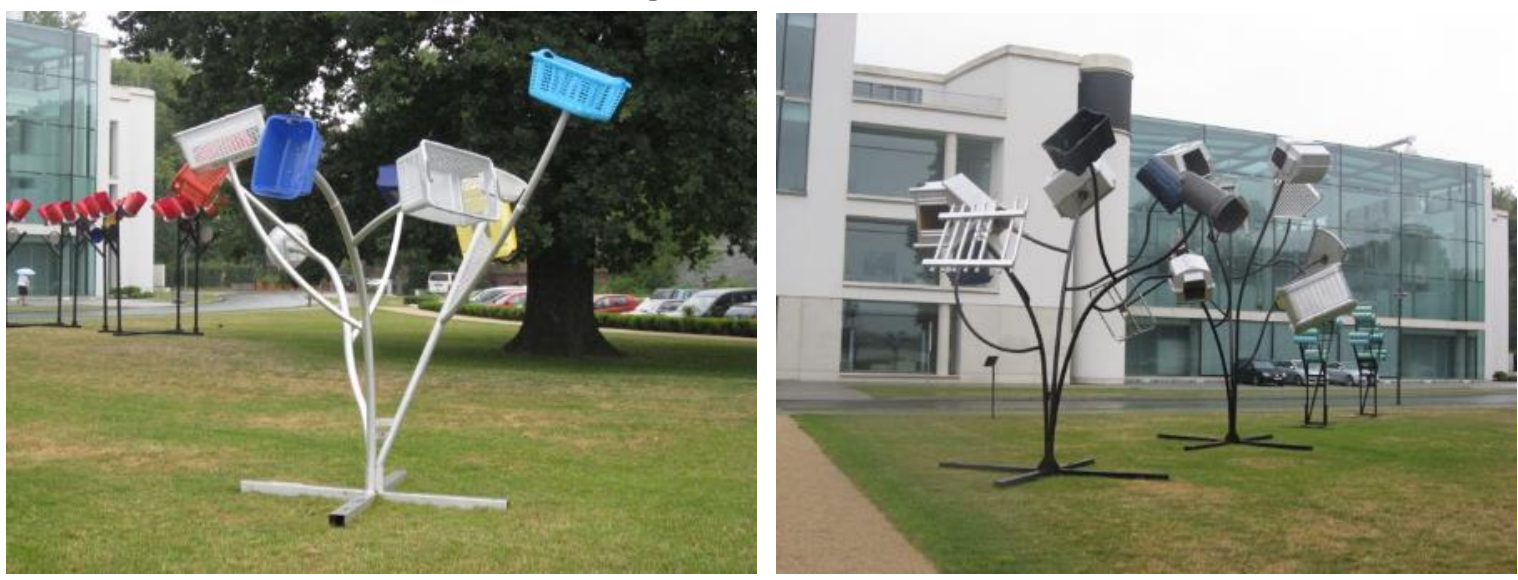

Fonte: Acervo das autoras.

Ou seja, Oppenheim amalgama natureza e cultura, fazendo buquês de flores com objetos descartáveis, de difícil decomposição, em uma crítica explícita à produção de lixo no planeta, transformando-as em obras de Arte Pública, ou seja, sem adicionar mais objetos, anteriormente inexistentes, ao ambiente urbano.

Trata-se de mais uma reflexão a ser feita, decorrente da presença de arte no espaço público. Arte Pública existe em muitos países. O fato de se impor ao olhar dos públicos algum artefato, uma obra de arte, nem sempre cumpre seu papel de questionar a vida, o mundo em que vivemos, a sociedade que estamos construindo, a herança que deixamos aos que nos sucederem. No caso de Oppenheim, temos um exemplo de uma contribuição questionadora, uma mostra de Arte Pública que não gera mais artefatos sobre a face da Terra, mas se apropria do que já existe para transformar em alguma coisa que não apenas marca o espaço público, como também nos leva a pensar sobre o quê nossos atos do presente deixam para o futuro. Trata-se de uma outra perspectiva para refletirmos sobre a implantação de arte nos espaços públicos, com um forte teor educativo. 


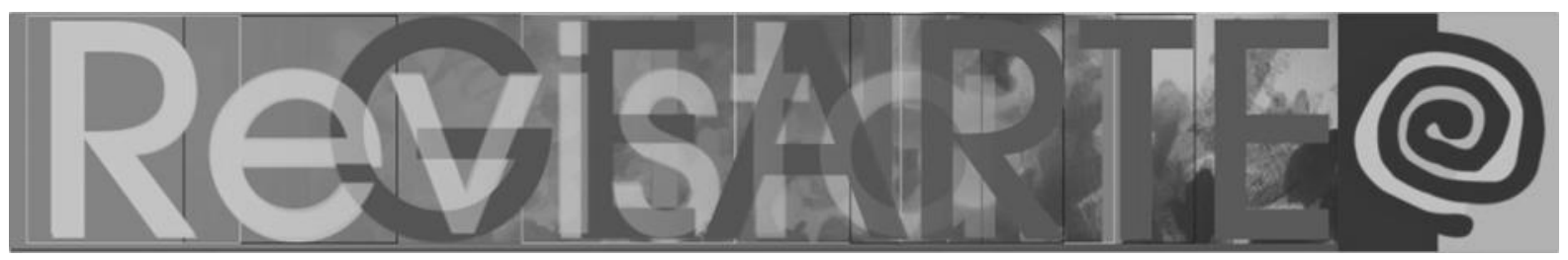

\section{Considerações: Arte Pública na educação}

Sabe-se da importância, no ensino de Arte, de os estudantes conhecerem diferentes produções, tanto artísticas quanto estéticas, de outros contextos e de onde vivem, e a Arte Pública se apresenta como potencial para isto. É notório que muitos professores enfrentam dificuldades para que seus alunos conheçam obras originais e muitas vezes é preciso recorrer a reproduções, que dificultam a percepção dos detalhes, dimensões, cores, enfim, elementos importantes no processo de apreensão de sentido. E entende-se que os professores, ao darem a conhecer a arte feita em sua região e seu contexto, podem trabalhar paralelamente com temas como identidade, história, memória, urbanismo, ecologia, além de outras especificidades de cada cidade, além de apreenderem as questões da arte.

No caso da cidade de Florianópolis, o acervo distribuído pela cidade possibilita criar circuitos que podem ser percorridos a pé, muitos deles próximos de instituições de ensino. A partir dele, o professor pode explorar diferentes aspectos, vinculando aos estudos em desenvolvimento e/ou utilizando a vasta produção em Arte Pública como eixo norteador para seu trabalho, podendo explorar não só a arte, portanto, mas também aspectos sociais e culturais, explorando inclusive outros sentidos além do visual. É nesta perspectiva que vem sendo realizada uma pesquisa de doutorado, intitulada "Arte Pública e Ação Educativa: interações de estudantes com o acervo do Município de Florianópolis", visando buscar estratégias para utilização desse acervo nas aulas de Arte, a partir dos resultados obtidos na visitação de circuitos por duas instituições, uma da rede particular e outra da rede pública. Como se dá a interação dos estudantes com a Arte Pública em Florianópolis? Essa é uma, dentre outras, questões que se quer buscar respostas.

O fato é que as obras de Arte Pública estão ali, presentes impositivamente, foram propostas e alocadas para serem vistas e apreendidas pelos sujeitos sejam eles estudantes ou não. Mas será que elas são percebidas? Por estar no espaço público, a Arte Pública torna-se mais acessível do que aquelas que se 


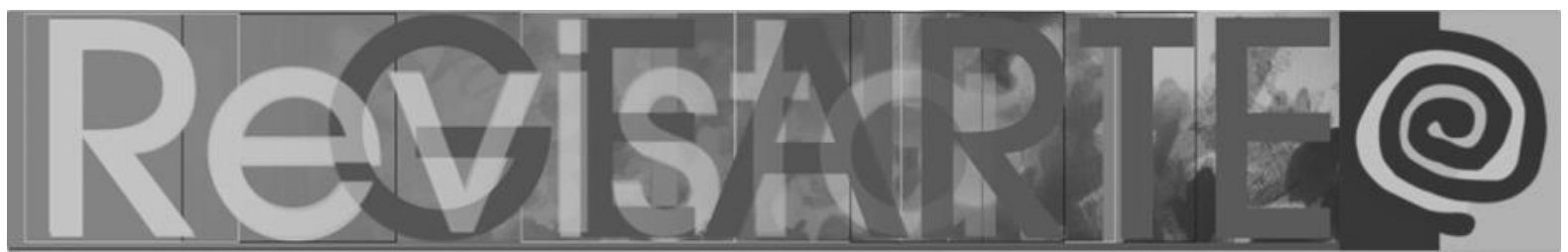

encontram nos espaços convencionais como museus e galerias? Utilizando as

palavras de Pallamin (2000, p. 48) "ela pode desabar pela indiferença”. Portanto, acredita-se na importância da educação para a valorização e aproximação da Arte Pública do sujeito, que por estar em local público já o torna público em potencial.

\section{Notas}

1 Sintetizando a proposição de Jan Mukarovsky (1993, p. 39-46), quando uma imagem tem, entre suas possíveis diversas funções a função estética, e ela não é a mais importante, mas sim outra função, utilitária, temos uma imagem estética, não artística; e quando nosso objeto tem, entre suas funções a função estética e ela é a de maior relevância, temos uma imagem (ou objeto, ou evento) artística(o).

2 A Lei tinha o seguinte teor: "Art. $1^{\circ}$ - Fica o Poder Executivo Municipal autorizado a fiscalizar a pintura de arte nas paredes externas das edificações com mais de 02 (dois) pavimentos, bem como a instalação de obra de arte na área interna e na área do afastamento frontal mínimo obrigatório, que sejam compatíveis com o projeto arquitetônico, se harmonizem com as cores do prédio e obedeçam a comunicação visual, para a quadra onde se situarem, previamente aprovada pelo IPUF. [...] Art. $4^{\circ}$ - As pinturas e obras de arte de que tratam esta Lei deverão ser originais, não se constituindo de reprodução ou réplica devendo, ainda, integrarem-se à estrutura arquitetônica da edificação. (FLORIANÓPOLIS, 1997, não paginada).

3 As obras dos primeiros anos ficavam dentro dos limites do condomínio, muitos deles cercados com muros de vidro ou grades que dificultavam a visibilidade do público.

4 As expressões individuais são aquelas relacionadas aos sujeitos que interferem na cidade - a obra de um artista, o edifício projetado pelo arquiteto, por exemplo, como também a maneira como os indivíduos usam aquilo que é posto nesse ambiente urbano. Paralelamente, também se tem ações urbanísticas propostas por gestores, que procuram deixar sua marca em um contexto mais amplo ou em edificações públicas específicas - a revitalização de grandes áreas, o estímulo à ocupação de regiões das cidades pouco habitadas, a edificação de pontes, dentre tantas outras.

\section{Referências}

ARGAN, Giulio Carlo. Storia dell'arte come storia della città. Roma: Reuniti, 1984.

CALVINO, Ítalo. As cidades invisíveis. São Paulo: Companhia das Letras, 1999.

EÇA DE QUIRÓZ, José Maria. A cidade e as serras. São Paulo: Difusão Cultural do Livro, 2006.

FÁVERO, Sandra Maria Correia. Arte ou não: uma abordagem de aspectos relacionados à formação de paradigmas estéticos do público. 2003. Dissertação (Mestrado em Engenharia de Produção) - Programa de Pós-Graduação em Engenharia de Produção, Universidade Federal de Santa Catarina, Florianópolis, 2003. Disponível em: <https://repositorio.ufsc.br/xmlui/handle /123456789/84848>. Acesso em: 11 dez. 2019.

FLORIANÓPOLIS. Lei n 3.255, de 3 de outubro de 1989. Autoriza a execução de pinturas e/ou obras de arte nas edificações, cria incentivo e dá outras providências. 1989. Câmara Municipal de Florianópolis. Disponível em: <http://www.cmf.sc.gov.br/legislacao>. Acesso em: 10 mai. 2019.

LANDOWSKI, Éric. Passions sans nom. Paris : Presses Universitaires de France, 2004.

LANDOWSKI, Eric. Interações arriscadas. São Paulo: Estação das Letras e Cores, 2014.

NUNES, Sandra Conceição; OLIVEIRA, Sandra Regina Ramalho e. Arte Pública: reflexões e possibilidades. 


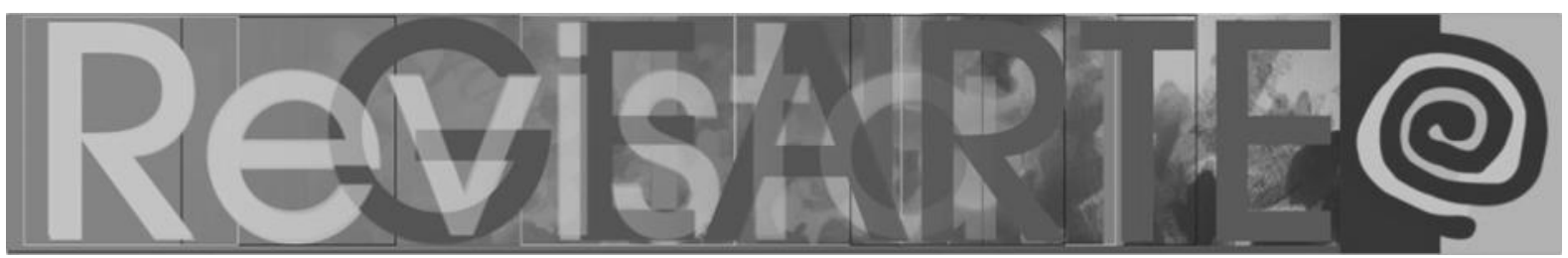

LANDOWSKI, Eric. Com Greimas: interações semióticas. São Paulo: Estação das Letras e Cores, 2017.

MUKAROVSKY, Jan. Estudos sobre Estética e Semiótica da Arte. Lisboa: Editorial Estampa, 1993.

PALLAMIN, Vera. Arte Urbana: São Paulo Região Central (1945-1998): obras de caráter temporário e permanente. São Paulo: Annablume: FAPESP, 2000.

RAMALHO E OLIVEIRA, Sandra. Diante de uma imagem. Florianópolis: Letras Contemporâneas, 2010.

\section{Sandra Conceição Nunes}

Doutoranda no Programa de Pós-Graduação em Artes Visuais (PPGAV/UDESC), linha de pesquisa: Ensino de Artes. Mestre em Artes Visuais pela UDESC (2010). Desde 2013 atua como Coordenadora de Artes Visuais da Fundação Cultural de Florianópolis Franklin Cascaes/Secretaria Municipal de Cultura, Esporte e Juventude. Foi membro da Diretoria da Associação de ArteEducadores de Santa Catarina (2007/2009). Membro da Comissão Municipal de Arte Pública de Florianópolis, desde 2015, e passou a integrar o Conselho Editorial da Fundação Cultural de Florianópolis Franklin Cascaes (FCFFC) em 2019.

ORCID: https://orcid.org/0000-0002-0002-0322

E-mail: sandranunes.arte@gmail.com

Currículo: http://lattes.cnpq.br/0518308143735228

\section{Sandra Regina Ramalho e Oliveira}

Professora e pesquisadora da Universidade do Estado de Santa Catarina/UDESC. É Doutora em Comunicação e Semiótica pela PUC/SP e fez pós-doutorado na França, em Semiótica Visual. Autora dos livros "Imagem também se lê", "Moda também é texto", "Sentidos à mesa" e "Diante de uma imagem", organizou, em coautoria, dez outros títulos de livros. Foi Presidente da ANPAP, gestão 2007-2008 e é membro das Associações Nacional e Internacional de Críticos de Arte, de Associações de Semiótica e de Ensino de Arte. Em 2020, foi Investigadora Visitante na Universidade de Girona, Espanha.

ORCID: https://orcid.org/0000-0002-6447-2096

E-mail: ramalho@floripa.com.br

Currículo: http://lattes.cnpq.br/0870589343786662

Recebido em 3 de janeiro de 2020 Aceito em 11 de janeiro de 2021 